Fournal of African Law, 45, 2 (2001), 227-229 (C) School of Oriental and African Studies. Printed in the United Kingdom.

\title{
STATUTE NOTE
}

\section{Land Acquisition Amendment Agt, 2000 (Zimbabwe)}

Since Zimbabwe became independent in 1980 the issue of land reform and, in particular, the issue of land acquisition and redistribution has seldom been off the political agenda. For the first ten years of independence there were constitutional constraints on the acquisition of land for resettlement purposes, but the National Land Policy of 1990 set out plans for an accelerated programme of resettlement. In order to achieve its ambitious targets the government of Zimbabwe saw the need to strengthen its powers of compulsory acquisition both by amending section 16 of the Constitution (which provided strong protection against the compulsory acquisition of property) and by enacting the Land Acquisition Adt to provide a statutory basis for the new policy. These reforms were extremely controversial both inside and outside the country and a clause excluding the right to fair compensation for expropriated land was dropped partly in response to international pressure.

During the 1990s, for a variety of reasons (not least a rapidly deteriorating economic situation), the acquisition of land for resettlement programme lagged far behind the targets set in the National Land Policy, and in the run-up to the general election in 2000 the land reform once again became a highly charged issue. Before the elections the ZANU (PF) government amended the Constitution and after the elections the same government (now with a much-reduced majority) amended the Land Acquisition Act, both measures designed to expedite the land reform programme. It is the purpose of this note to examine these changes 3

The principal effect of the constitutional amendments is to place on Britain ("the former colonial power") the responsibility for establishing a fund for the payment of compensation for agricultural land compulsorily acquired for resettlement and at the same time to relieve the government of Zimbabwe of any obligation to pay such compensation. Even where compensation is payable for the land, there is no requirement that it should be "fair" or "adequate" or represent the market value of the land. Indeed an assessment must take into account a wide variety of factors including "the history of the ownership, use and occupation of the land", "the resources available to the acquiring authority in implementing the programme of land reform" and "any financial constraints that necessitate the payment of compensation in instalments over a period of time's

Constitution of Zimbabwe Amendment Act (No. 11), No. 30 of 1990

2 See Simon Coldham, "The Land Acquisition Act, 1992, of Zimbabwe", (1993) f.A.L. 82; Gino Naldi, "Land Reform in Zimbabwe: Some Legal Aspects", (1993) 31(4) Fournal of Modern African Studies 585; Isaac Maposa, Land Reform in Zimbabwe, Catholic Commission for Justice and Peace in Zimbabwe, 1995.

${ }^{3}$ In the meantime the extra-legal acquisition and redistribution of commercial farms have to some extent pre-empted the introduction of the new regime.

${ }_{4}^{4} \mathrm{~S}$. 16A(1) of the Constitution inserted by the Constitution of Zimbabwe Amendment (No. 16) Act, No. 5 of 2000 , s. 3 .

5 S. $16 \mathrm{~A}(2)$. 
With the constitutional amendments in place it was now open to the goyernment to amend the Land Acquisition Act. This was done with a certain haste Rather than enact a new acquisition law, the government rushed through, with minimal discussion, a large number of amendments to the 1992 Act. The most controversial of these amendments related to compensation. As under the previous law, the assessment of compensation is to be carried out by the Compensation Committee after it has received a preliminary estimate of compensation prepared by a designated valuation officer 7 However, the principles upon which compensation is assessed are new. In the absence of any special fund being established by Britain, compensation is payable only for "any improvements on or to the land", and not for the land itself 9 While the assessment must take into account "the age, nature and condition of the improvements" as well as a number of factors relating to specific kinds of improvement, it remains unclear how an improvement is to be valued. 9 As under the 1992 Act, there is provision for an appeal to the Administrative Court against the assessment made by the Committee, but only on the basis that the Committee did not observe any of the principles set out in the Act 10 There is no appeal on the basis that the assessment was not "fair". Indeed, given the political and economic constraints to which the government of Zimbabwe is currently subject, it seems unlikely that compensation payments for improvements will be generous ${ }^{11}$ Finally, it should be emphasized that these provisions apply only to the acquisition of agricultural land for resettlement. There is no obligation on the government to show that the land is suitable for resettlement; indeed, it appears that all rural land falls into this category.12

Although the provisions regarding compensation were the ones that attracted most publicity, the Act contains several amendments intended to remove bottlenecks and to put land reform on the "fast track". One notable example is the abolition of the land designation procedure. This procedure, introduced in 1992, was designed to facilitate the acquisition of large blocks of land for settlement schemes as well as to aid planning. There might be good reasons (typically financial) why the government could not acquire immediately a large block of land; instead it could designate the land for acquisition within ten years. Whatever the merits or otherwise of the designation procedure, it became redundant when

\footnotetext{
${ }^{6}$ It may have been seen as a matter of political necessity. As the Minister of Justice said in the debates: "The sad thing is that there would be other processes to deliver a solution." Parliamentary Debates, Vol. 27, No. 26, Col. 2593 (31 October, 2000).

7 The Compensation Committee has been enlarged. Whereas under the 1992 Act it consisted of three public officers (ex officio) together with not more than three other members appointed by the Minister of Lands, it now consists of six public officers together with not more than five other members appointed by the Minister. Land Acquisition Act s. 29(A).

8 Land Acquisition Act s. 29C(1).

9 The principles are set out in Part I of the new Schedule to the Act. Compensation is clearly not based on the original cost of making the improvement nor on the estimated cost of making the improvement at the time of the notice of acquisition. Moreover, to value improvements by subtracting the value of the unimproved land from the value of the improved land would be problematic.

10 S. 29D. Appeal lies to the Supreme Court.

11 Whereas under the 1992 Act at least half of the compensation payable should be paid at the time the land is acquired or within a reasonable time thereafter, under the new section 29C(3) only one quarter is payable at that time, a further quarter being payable within two years and the balance within five years.

12 In the debates on the Bill the Minister of Justice stated: "It depends on what settlement scheme you apply to any piece of land. Wild life management and farming can be a settlement scheme.... There is no land here which is not suitable for agricultural purposes." Parliamentary Debates, Vol. 27, No. 26, Col. 2669 (31 October, 2000).
} 
the government had the power to acquire land without compensation except for improvements.

Controversial though they may be, these amendments to the law undoubtedly make it much easier for the government to acquire land for resettlement purposes. However, in the short term at least, land redistribution will result in a loss of production and may destabilize agricultural investment, employment, food security and export earnings. Moreover, the settlement schemes of the 1980s and 1990s have a rather uneven record and it is likely that in the longer term, without proper planning, without infrastructural investment, without security of tenure and without appropriate criteria for the selection of settlors, these schemes are unlikely to prosper, let alone to solve the problem of poverty and landlessness in the Communal Areas. The compulsory acquisition of land may be much easier today, but, in the political and economic circumstances in which Zimbabwe currently finds itself, the effective redistribution of land would appear to be still a long way off.

Simon Coldham 